\begin{tabular}{llllllllllll}
$\mathbf{B}$ & $\mathbf{I}$ & $\mathbf{B}$ & $\mathbf{L}$ & $\mathbf{I}$ & $\mathbf{O}$ & $\mathbf{G}$ & $\mathbf{R}$ & $\mathbf{A}$ & $\mathbf{F}$ & $\mathbf{I}$ & $\mathbf{A}$ \\
\hline
\end{tabular}

ROCZNIKI TEOLOGICZNE

$\underline{\text { Tom LXVII, zeszyt } 7-2020}$

PIOTR KOPIEC

DOI: https://dx.doi.org/10.18290/rt20677-18

\title{
BIBLIOGRAFIA PRACOWNIKÓW INSTYTUTU EKUMENICZNEGO/SEKCJI EKUMENIZMU INSTYTUTU NAUK TEOLOGICZNYCH KUL W 2019 ROKU
}

KS. PROF. DR HAB. MAREK J A G O D Z I Ń S K I

I. ARTYKUŁY NAUKOWE

- The Father in the Communion of the Holy Trinity, „Teologia w Polsce” 13 (2019) nr 1, s. 5-17.

- Komunijno-trynitarna pozycja Ducha Świętego, „Roczniki Teologiczne” 66 (2019), z. 7: Teologia ekumeniczna, s. 5-20.

- Duch Święty w kontekście współczesnej teologii komunijnej, „Teologia w Polsce” 13 (2019), nr 2, s. 151-164.

II. RECENZJE

- Między Bogiem, prawem $i$ wolnościa, rec. Edward Sienkiewicz, Boże prawo a wolność. Od prawa boskiego króla do narodu Prawa, Rozprawy i Studia / Uniwersytet Szczeciński, ISSN 0860-2751, t. (1143)1069, Szczecin: Wydawnictwo Naukowe Uniwersytetu Szczecińskiego 2019, ss. 227. ISBN 978-83-7972-275-4, „Roczniki Teologiczne” 66 (2019), z. 7: Teologia ekumeniczna, s. 183-187.

- Paleta teologii współczesnych, rec. Andrzej NAPIóRKowski OSPE, Teologie XX i XXI wieku, Źródła Myśli Teologicznej 37, Kraków: Wydawnictwo WAM 2016, ss. 448. ISBN 978-83-277-1124-3, „Roczniki Teologiczne” 66 (2019), z. 7: Teologia ekumeniczna, s. 187-190.

Dr hab. Piotr Kopiec, prof. KUL - Katolicki Uniwersytet Lubelski Jana Pawła II, Wydział Teologii, Instytut Nauk Teologicznych, Sekcja Ekumenizmu, Katedra Teologii Protestanckiej; adres do korespondencji — e-mail: petrko@kul.pl. ORCID: https://orcid.org/0000-0002-0581-0737. 


\section{PRZEKŁADY}

- Anton Štrukelo, Zaufanie. Odwaga bycia chrześcijaninem (Vertrauen. Mut zum Christsein, EOS Verlag, St. Ottilien 2012), tłum. Marek Jagodziński, wyd. poszerzone, Wydawnictwo Diecezji Radomskiej AVE, Radom 2019, ss. 340.

Ks. DR hAB. PrZEMYSŁaW KANTYKa, Prof. KUL

\section{ARTYKUŁY NAUKOWE}

- Sprawiedliwość ekologiczna. Programy Światowej Rady Kościołów na rzecz zachowania środowiska naturalnego, „Roczniki Teologiczne” 66 (2019), z. 7: Teologia ekumeniczna, s. 117-129.

- Ten years of Ordinariates for Anglicans - a few reflections on the new ecclesiological model, „Studia Oecumenica” 19 (2019), s. 7-18.

II. RECENZJE WYDAWNICZE

- Anton Štrukelu, Zaufanie. Odwaga bycia chrześcijaninem, tłum. Marek Jagodziński, Radom: Wydawnictwo Diecezji Radomskiej 2019, ss. 340.

III. SPRAWOZDANIA

- Działalność naukowa Instytutu Ekumenicznego KUL w 2018 roku, „Roczniki Teologiczne" 66 (2019), z. 7: Teologia ekumeniczna, s. 195-209.

DR HAB. PIOTR K O P I E C

\section{ARTYKULY NAUKOWE}

- The idea of the Biblical economics: Utopia or chance in the face of the contemporary transformations of the sphere of work, „HTS Teologiese Studies / Theological Studies" 4 (75), 2019.

- Pojęcie światopoglądu ekumenicznego i jego znaczenie dla ekumenizmu, „Studia Theologica Varsaviensia" 57 (1) (2019), s. 157-176.

- Idolatria kapitalizmu w perspektywie teologii luterańskiej, „Roczniki Teologiczne" 66 (2019), z. 7: Teologia ekumeniczna, s. 151-182.

- Ruch ekumeniczny wobec współczesnych przemian w sferze pracy i ich konsekwencji dla rodziny: diagnozy i propozycje Konferencji Kościotów Europejskich, „Forum Teologiczne” 20 (2019), s. 75-87.

- Milczenie Boga: przykłady żydowskiej i chrześcijańskiej teologii Holocaustu (Paul van Buren i Richard L. Rubenstein), „Przegląd Humanistyczny” 63(3) (2019), s. 61-76.

- New Voices in the Grassroots Ecumenism: An Outline of the Postcolonial Theological Thought, „Studia Oecumenica” 19 (2019), s. 19-31. 
II. SPRAWOZDANIA

- „Narody i Kościoly. Ekumeniczna odpowiedź na nacjonalizm i migrację”. XX konsultacje akademickie Europejskiego Stowarzyszenia Badań Ekumenicznych Societas Oecumenica, Ludwigshafen 23-28 sierpnia 2018 r., „Roczniki Teologiczne" 66 (2019), z. 7: Teologia ekumeniczna, s. 191-194.

- Bibliografia pracowników Instytutu Ekumenicznego KUL (rok 2018), „Roczniki Teologiczne" 66 (2019), z. 7: Teologia ekumeniczna, s. 211-215.

- 45 Kongres Międzynarodowej Wspólnoty Ekumenicznej „Mitość Chrystusa przynagla nas” (2 Kor 5:14), Kraków22-29 lipca 2019 r., „Nurt SVD” 2 (2019), s. 294-296.

Prof. DR HAB. KRZYSZTOF L E Ś N I E W S K I

\section{ARTYKUŁY NAUKOWE}

- Primejdiile spiritual pentru fiinta umana asa cum sunt ele prezentate in Canonul Cel Mare al Sfantului Andrei Criteanul, „Orientalia Patristica” 2019, s. 322-342.

- Kwestia prokreacji w prawostawiu, „Studia Oecumenica” 19 (2019), s. 179-192.

- The Ethos of God and Man in Christos Yannaras' Works, „Roczniki Teologiczne" 66 (2019), z. 7: Teologia ekumeniczna, s. 51-68.

- Tears in the Hesychastic Tradition, „Rocznik Teologiczny ChAT” 61 (2019), z. 3, s. 501-523.

II. ROZDZIAŁY W MONOGRAFIACH WIELOAUTORSKICH

- Misja w Kościele prawostawnym, w: Misja: istota i chwata Kościoła katolickiego, red. Andrzej Napiórkowski, Kraków: Wydawnictwo Naukowe Papieskiego Uniwersytetu Jana Pawła II w Krakowie 2019, s. 313-327.

Ks. DR HAB. SŁAWOMIR P A W Ł O W S K I SAC, PROF. KUL

I. WSPÓŁREDAKCJA PUBLIKACJI ZBIOROWYCH

- Życzliwymi bądźmy (por. Dz 28,2). Materiały na Tydzień Modlitw o Jedność Chrześcijan 18-25 stycznia i cały rok 2020, red. Andrzej Gontarek, Sławomir Pawłowski, Edward Puślecki, Doroteusz Sawicki, Kalina Wojciechowska, Warszawa: Rada ds. Ekumenizmu Konferencji Episkopatu Polski i Polska Rada Ekumeniczna 2019. ISSN 0208-9424.

KS. DR HAB. TOMASZ S I E M I E N I E C

\section{ARTYKUŁY NAUKOWE}

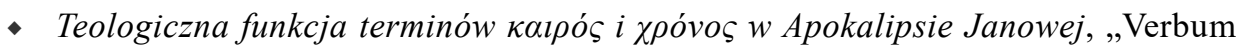
Vitae" 35 (2019), s. 307-342. 
II. ROZDZIAE W MONOGRAFII WIELOAUTORSKIEJ

- Grzegorz Wielki jako egzegeta w świetle „Homilii na Ksiegę Ezechiela”, w: Homilie na Księge Ezechiela. Cz. 2. Grzegorz Wielki, red. Adam Wilczyński, Tyniec: Wydawnictwo Benedyktynów 2019, s. 9-36.

III. RECENZJE

- [Janusz M. Czerski, Apokalipsa Świętego Jana. Wstęp i Komentarz. I. Ap 1-3. II. Ap 4-13 Opole: Redakcja Wydawnictw Wydziału Teologicznego Uniwersytetu Opolskiego 2018-2019], „Verbum Vitae” 36 (2019), s. 497-504. 